\title{
A rare presentation of eyelid tuberculosis
}

Woon Tian Qing ${ }^{1,2}$, Noorlaila Bt Baharuddin ${ }^{1}$, Nor Fadzillah Bt Abd Jalil ${ }^{1}$, Raja Norliza Raja Omar ${ }^{1}$, Wan Haslina Wan Abdul Halim²

${ }^{1}$ Department of Ophthalmology, Hospital Melaka, Melaka, Malaysia ; ${ }^{2}$ Department of Ophthalmology, Universiti Kebangsaan Medical Centre (UKMMC), Kuala Lumpur, Malaysia

\section{Abstract}

Mycobacterium tuberculosis is transmitted through aerosolization, hence commonly infects the lungs. The occurrence of extrapulmonary tuberculosis is rare. We report a case of eyelid tuberculosis in a 45-year-old gentleman with a history of treated testicular tuberculosis three years ago. He had insidious onset of painless swelling in the right upper eyelid associated with erythema for one month. He did not have other constitutional symptoms. Initially, he was treated as chalazion and given topical antibiotics. However, the swelling worsened despite medication. His best corrected visual acuity was 6/9 in both eyes. Examination showed an elevated ulcerative growth with broad base which bled easily upon touch. The clinical presentation varies from an eyelid infection as an eyelid tumour can be a diagnostic challenge. A slow response to oral and topical antibiotic warrants an excision biopsy. The results showed chronic granulomatous infection in acid-fast bacilli. An antituberculosis (anti-TB) therapy was started and the patient showed a positive clinical response.

Althrough rare, tuberculosis of eyelid should be considered as differential diagnosis of chalazion. Any suspicious case should be confirmed by biopsy followed by anti-TB if indicated.

Keywords: acid-fast bacilli, chalazion, eyelid, tuberculosis

Correspondence: Woon Tian Qing, Department of Ophthalmology, Universiti Kebangsaan Medical Centre (UKMMC), Jalan Yaacob Latif, Bandar Tun Razak, 56000, Cheras, Kuala Lumpur, Malaysia.

E-mail:woontq@yahoo.com 


\section{Manifestasi ganjil tuberculosis kelopak mata}

\section{Abstrak}

Mycobacterium tuberculosis ditularkan melalui aerosol, dan biasanya menjangkiti paru-paru. Kejadian tuberkulosis extrapulmonary jarang berlaku. Kami melaporkan kes tuberkulosis kelopak mata pada lelaki berusia 45 tahun dengan sejarah tuberkulosis testicular yang dirawat tiga tahun yang lalu. Dia mengalami permulaan bengkak yang tidak menyakitkan di kelopak mata sebelah kanan berserta eritema selama sebulan. Dia tidak mempunyai gejala lain. Pada mulanya, dia dianggap sebagai chalazion dan diberikan antibiotik topikal. Bagaimanapun, bengkak menjadi lebih teruk walaupun diberi ubat. Ketajaman penglihatannya yang terbaik adalah 6/9 di kedua-dua mata. Pemeriksaan menunjukkan satu ulser yang menimbul dengan dasar yang luas mudah berdarah apabila disentuh. Manifestasi klinikal ini berbeza dari jangkitan kelopak mata sebagai tumor kelopak mata yang boleh menjadi cabaran diagnostik. Tindakbalas yang perlahan terhadap antibiotik oral dan topikal memerlukan biopsi untuk pengesahan. Hasilnya menunjukkan jangkitan granulomatous kronik dalam bakteria bersifat bacilli asid cepat. Terapi antituberculosis (anti-TB) bermula dan pesakit menunjukkan tindak balas klinikal yang positif.

Walaupun jarang, tuberkulosis kelopak mata perlu dipertimbangkan sebagai diagnosis dan membezakan dengan chalazion. Mana-mana kes yang mencurigakan perlu disahkan oleh biopsi diikuti dengan anti-TB jika disahkan.

Kata kunci: bacilli asid-cepat, chalazion, kelopak mata, tuberculosis

\section{Introduction}

Mycobacterium tuberculosis is transmitted through aerosolization, hence commonly infects the lungs. The occurrence of extrapulmonary tuberculosis is rare: only $1-2 \%$ of patients with ocular tuberculosis have an existing systemic manifestation. ${ }^{1}$ Ocular tuberculosis commonly presents with anterior uveitis and choroiditis due to haematogenous spread or hypersensitivity response to the tuberculosis antigen followed by systemic infection. Eyelid tuberculosis is a rare presentation of ocular tuberculosis, usually secondary to orbital involvement with drainage sinus. ${ }^{2}$ 


\section{Case report}

A 45-year-old gentleman presented with painless swelling in the right upper eyelid with erythema for one month (Fig. 1a). He was initially treated as internal hordeolum and given topical antibiotics by a private practitioner. However, the swelling worsened despite treatment and there was accelerated submandibular lymphadenitis. He had a history of testicular tuberculosis three years ago and completed antitubercular agents (Akurit four four tablets OD) for six months. The testicular tuberculosis resolved with treatment. He was immunocompetent and did not have other constitutional symptoms.

On examination, his best corrected visual acuity was 6/9 in both eyes. There was an elevated ulcerative growth with broad base at the right upper lid which bled easily bleeds upon touch (Fig. 1b). An excision biopsy was performed on the eyelid lesion. The histology showed granuloma with presence of epithelioid histiocytes and Langhan's giant cell (Fig. 2). On Ziehl Nelson staining, there was presence of acid-fast bacillus indicating eyelid tuberculosis. Other investigations, such as chest X-ray and Mantoux test, were normal. An antitubercular therapy (Akurit 4 four tablets OD) was started for six months and the patient showed significant improvement. There was

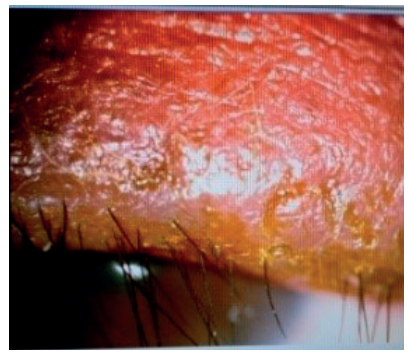

Fig. 1a. Anterior view of the lid pre-excision.

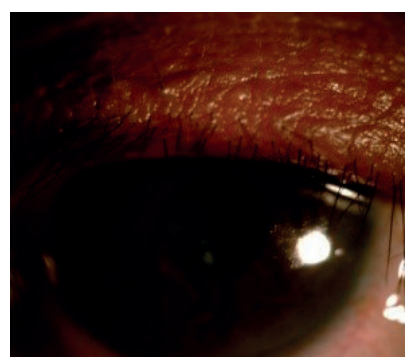

Fig. 2a. Post-excision and after initiation of antituberculosis treatment.

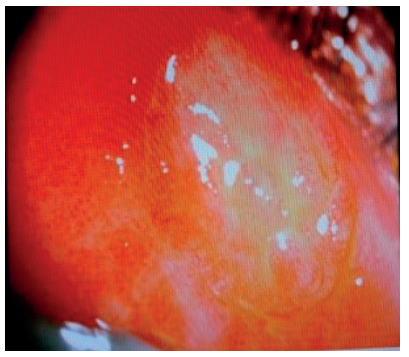

Fig. 1b. Everted lid pre-excision.

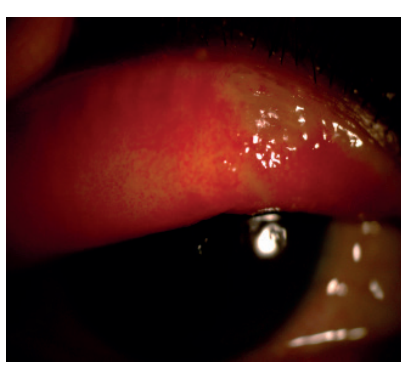

Fig. 2b. The lesion flattened two weeks post-excision and initiation of antituberculosis treatment. 
regression of the lymphadenitis and the eyelid swelling resolved (Fig. 3a). The lesion at the eyelid healed and flattened (Fig. 3b) two weeks after starting therapy.

\section{Discussion}

Ocular tuberculosis was reported as choroidal tuberculoma in 1830 by Gueneau de Mussy. ${ }^{3}$ Ocular tuberculosis can be caused by Mycobacteria species such as tuberculosis, bovis, microti, and africanum surrounding the eyes. ${ }^{4}$ Primary ocular tuberculosis is isolated from systemic infection. Secondary ocular tuberculosis is caused by direct hematogenous spread or contagious spread from infected structures by introduction of bacilli through epithelial injury. ${ }^{5}$ Ocular tuberculosis usually present as unilateral, painless, and progressively enlarging eyelid swelling associated with injected conjunctiva and chemosis.

Eyelid involvement by tuberculosis is commonly secondary to orbital involvement and often seen in the form of drainage sinus. Diagnostic imaging, such as computed tomography (CT), was not done in this patient to evaluate the sinus cavities because the lesion was isolated at the palpebral conjunctiva and there was no discharge from the sinus. In our case, the patient presented with eyelid swelling mimicking eyelid infection or eyelid tumour. There were no other systemic infectious signs beside the presence of submandibular lymphadenitis. The diagnosis can thus be difficult and may require an orbital biopsy in which acid-fast bacilli and the characteristic histopathology may be seen. The growth of Mycobacterium tuberculosis from the specimen remains the gold standard for the diagnosis of tuberculosis. ${ }^{6}$ Delay in diagnosing eyelid tuberculosis can lead to tarsal plate destruction, lagophthalmos, skin fistula, and cicatricial ectropion. ${ }^{7,8}$ Therefore, when the patient does not respond to conventional anti-inflammatory and antibiotic therapy, a revision of the diagnosis is important.

\section{Conclusion}

Tuberculosis can affect the orbit and external eye in a wide variety of ways. Accurate diagnosis and prompt treatment are important to reduce the occurrence of associated complications.

\section{References}

1. Extrapulmonary tuberculosis. Available at: https://en.wikipedia.org/wiki/Tuberculosis\#Extrapulmonary.

2. Helm CJ, Holland GN. Ocular tuberculosis. Surv Ophthalmol. 1993;38(3):229-56. 
3. Bajaj DK, Srivastava A, Kushwaha RA, et al. Two cases of eyelid tuberculosis - An uncommon presentation of ocular tuberculosis. Indian J Tuberc. 2017;64:47-49. doi:10.1016/j.ijtb.2016.06.004.

4. R. Agrawal, S. Agrawal. Isolated right upper eyelid tuberculosis: A case report with review of the literature. J Clin Diagn Res. 2012;6(6):1068-1069.

5. R. Mittal. Tuberculosis of eyelid presenting as a chalazion. Available at: https://www.aaojournal.org/ article/S0161-6420(12)01179-7/pdf. 